\title{
SIMULASI BIAYA PENANGANAN JALAN ANTARA PERKERASAN KAKU DAN PERKERASAN LENTUR
}

\author{
Ade Mulyawan ${ }^{1)}$, Sofyan M. Saleh ${ }^{2)}$, Renni Anggraini ${ }^{3)}$ \\ Prodi Magister Teknik Sipil, Jurusan Teknik Sipil, Universitas Syiah Kuala \\ Jalan Tgk. Syech Abdurrauf No. 7 Darussalam Banda Aceh \\ Email: mulya.mulyawan2@gmail.com ${ }^{1)}$, sofyan.saleh@unsyiah.ac.id ${ }^{2)}$, \\ renni.anggraini@unsyiah.ac.id ${ }^{3)}$ \\ Corresponding author: sofyan.saleh@unsyiah.ac.id
}

DOI: http://dx.doi.org/10.29103/tj.v9i2.224

(Received: May 2019 / Revised: July 2019 / Accepted: August 2019)

\begin{abstract}
Abstrak
Perkerasan jalan di Indonesia umumnya tipe perkerasan lentur dengan pertimbangan biaya pembangunan (initial cost) yang lebih murah, keterbatasan anggaran serta tuntutan pemerataan pembangunan. Pemilihan perkerasan lentur diprediksikan memiliki biaya total pemeliharaan/penanganan jalan yang lebih mahal dibandingkan dengan perkerasan kaku. Penelitian ini mengkaji perbandingan biaya penanganan/ pemeliharaan jalan antara perkerasan kaku dengan perkerasan lentur dengan budget plan analysis selama periode analisis 40 tahun. Metode analisis yang digunakan adalah permodelan penurunan kondisi perkerasan jalan (road deterioration model) berdasarkan nilai International Roughness Index (IRI) dan umur masa layan sebagai variabel utama berdasarkan rumus dan pendekatan yang digunakan pada manual HDM-4 Versi kedua. Adapun variabel perbandingan yang digunakan adalah biaya pembangunan, biaya pemeliharaan tahunan dan biaya total selama 40 tahun. Hasil penelitian menunjukkan bahwa biaya pembangunan perkerasan kaku lebih mahal $33,630 \%$ dari perkerasan lentur. Pada perkerasan kaku, biaya rerata keseluruhan penanganan per tahun lebih hemat $45,98 \%$, biaya rerata pemeliharaan (termasuk rekonstruksi) perkerasan kaku lebih hemat $64,12 \%$, biaya rerata pemeliharaan (tanpa rekonstruksi) lebih hemat $18,59 \%$ dan biaya kumulatif budget plan selama periode analisis 40 tahun pada perkerasan kaku lebih hemat 45,98\% lebih ekonomis dibandingkan dengan perkerasan lentur. Berdasarkan Budget Plan Analysis, perkerasan kaku memiliki biaya pembangunan yang lebih mahal namun memiliki biaya pemeliharaan dan biaya total penanganan jalan yang jauh lebih hemat dibandingkan perkerasan lentur.
\end{abstract}

Kata Kunci: perkerasan kaku, perkerasan lentur, budget plan analysis, road deterioration model.

\begin{abstract}
Type of pavements that generally uses in Indonesia is flexible pavement with consideration of less initial costs, budget constraints, and demands for equitable development. The flexible pavement is predicted to have a higher total cost of road maintenance, which is more expensive than rigid pavement. This study examines the comparison of road maintenance cost between flexible and rigid pavement with budget plan analysis during the 40 -year of the service life. The analytical method in this study is performed using HDM-4 in which is the modeling of road deterioration based on International Roughness Index (IRI) and service life variables. The
\end{abstract}




\begin{abstract}
comparison variables used are construction costs, annual maintenance costs, and total costs of road maintenance for 40 years. The results showed that the initial cost of rigid pavement is $33.63 \%$ more expensive than flexible pavement. On rigid pavement, the overall average cost of road treatment per year is more efficient 45.98 $\%$, the average of annual maintenance costs (including reconstruction costs) of rigid pavement is saving more $64.12 \%$, the average of annual maintenance costs (excluding reconstruction costs) of rigid pavement is saving more $18.59 \%$ and the cumulative cost of the budget plan for a 40 -year analysis period on the rigid pavement is more economical $45.98 \%$ compared to flexible pavement. Based on Budget Plan Analysis, the initial cost of rigid pavements are more expensive but the rigid pavements have much lower maintenance costs and total cost of road treatment compared to the flexible pavement.
\end{abstract}

Keywords: rigid pavement, flexible pavement, budget plan analysis, road deterioration model.

\title{
1. Latar Belakang
}

Jenis perkerasan jalan yang umum digunakan di Indonesia adalah perkerasan lentur dimana pemilihan konstruksi perkerasan lentur ini disebabkan oleh karena biaya pembangunan (initial cost) yang lebih murah bila dibandingkan konstruksi perkerasan kaku yang lebih mahal. Selanjutnya, selain initial cost, faktor keterbatasan anggaran, dan tuntutan pemerataan pembangunan menjadikan tipe jalan perkerasan lentur dianggap menjadi opsi paling baik dan rasional mengingat segala hambatan dan keterbatasan yang ada. Pemilihan tipe perkerasan jalan juga perlu mempertimbangkan aspek lainnya seperti biaya pemeliharaan selama masa layan, tingkat umur layan dari suatu tipe perkerasan jalan dan juga ketahanan terhadap lalu lintas berat termasuk beban berlebih (overloading). Menurut Saleh et al (2009) menyatakan bahwa muatan truk berlebih mencapai $50 \%$ dapat mempengaruhi biaya pemeliharaan 2,5 kali terhadap biaya rencana pemeliharan rutin per tahun dalam rentang waktu masa layan. Selanjutnya Syafriana et al (2015) juga menyatakan bahwa total kendaraan yang melakukan pelanggaran terhadap jumlah berat yang diizinkan (JBI) rata-rata perhari sebanyak 31,50\% terhadap jumlah total kendaraan barang pada ruas jalan lintas timur Provinsi Aceh. Dalam hal umur layan, perkerasan kaku memiliki umur layan yang lebih panjang yakni 35-45 tahun dibandingkan dengan perkerasan lentur yang berkisar 15-20 tahun. Berdasarkan beberapa hal tersebut di atas dan tipe perkerasan kaku memiliki tingkat ketahahan yang lebih baik dalam memikul beban kendaraan berat termasuk beban berlebih. Dalam pelaksanaannya tidak diketahui seberapa besar tingkat keekonomisan dari perbandingan kedua perkerasan tersebut. Penelitian ini bertujuan untuk mengetahui tingkat perbandingan biaya penanganan jalan antara perkerasan lentur dengan perkerasan kaku dengan periode analisis selama 40 tahun. Pada penelitian ini, nilai manfaat (user cost) pada perkerasan kaku dan lentur diasumsikan sama sehinggga nilai manfaat dapat diabaikan dan penelitian akan fokus pada analisis pada initial cost dan biaya pemeliharaan (maintenace cost) sehingga dapat diketahui biaya penanganan jalan yang paling efisien dan ekonomis antara kedua tipe perkerasan tersebut berdasarkan Budget Plan Analysis dengan permodelan penurunan kondisi jalan bebasis nilai IRI (International Roughness Index) dengan periode analisis selama 40 tahun. 


\section{Metode Penelitian}

\subsection{Gambaran umum penanganan jalan}

Budget Plan merupakan suatu rencana penyusunan strategi penggunaan sejumlah alokasi dana yang diusulkan oleh suatu instansi untuk dipergunakan atau dibelanjakan dalam periode waktu tertentu untuk menjalankan tugas atau fungsi yang menjadi tanggung jawab instansi tersebut. Analisis budget plan menggunakan teknik analisis berdasarkan prinsip ekonomi untuk memprediksi tingkat perubahan nilai uang pada masa yang akan datang selama periode analisis (future cost). Analisis budget plan digunakan untuk memprediksi kebutuhan anggaran yang diperlukan untuk penanganan jalan selama periode analisis tertentu terhadap beberapa alternatif penanganan dalam penelitian ini yakni antara perkerasan kaku (rigid pavement) dan perkerasan lentur (flexible pavement).

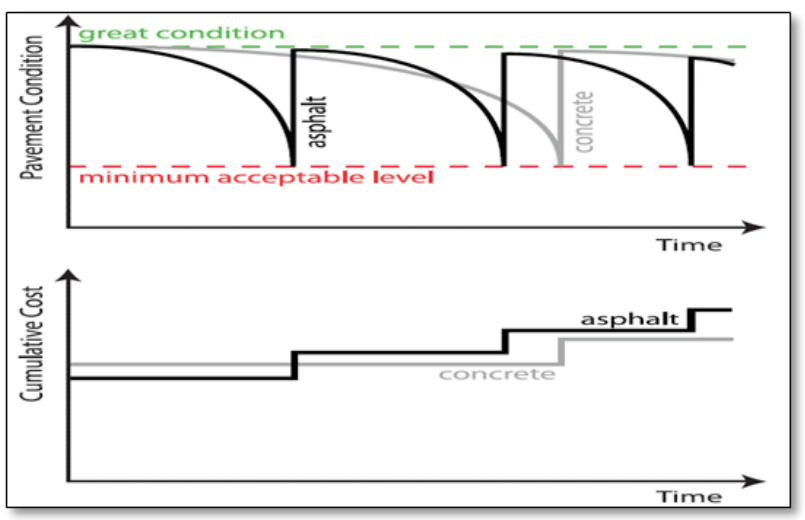

Gambar 1 Ilustrasi kondisi perkerasan jalan terhadap waktu dan dampak finansial pada perhitungan keseluruhan biaya penanganan jalan (ACPA 2012)

\subsection{Perencanaan desain dan manajemen pemeliharaan jalan}

Perencanaan desain perkerasan lentur dan kaku dihitung berdasarkan Direktorat Jenderal Bina Marga (2017) dengan umur layan rencana 20 tahun untuk perkerasan lentur dan 40 tahun untuk perkerasan kaku, faktor laju pertumbuhan $4,83 \%$ pertahun dan umur layan pondasi 40 tahun.

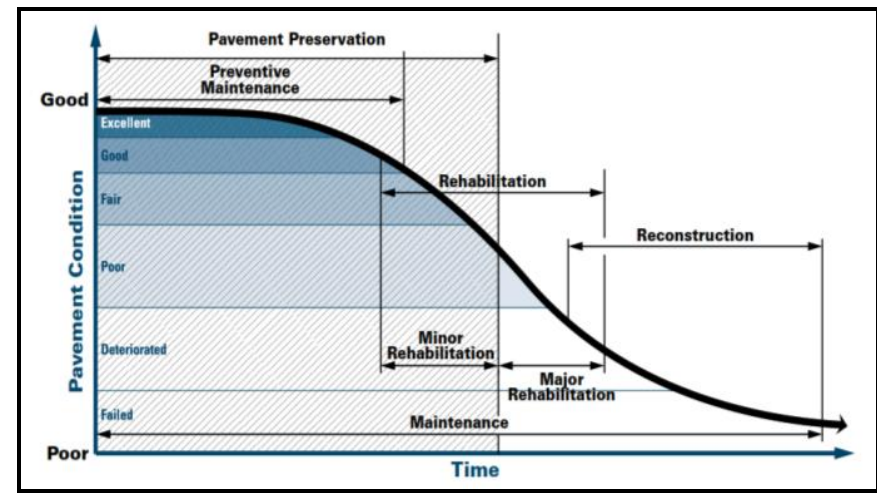

Gambar 2 Ilustrasi pengertian pemeliharaan, rehabilitasi dan rekonstruksi

Robinson dan Thagesen (2004) menyatakan bahwa manajemen jalan merupakan sebuah proses untuk mengoptimalkan keseluruhan kinerja jaringan jalan dari waktu ke waktu. Federal Highway Administration of U.S Department of

Simulasi Biaya Penanganan Jalan Antara Perkerasan Kaku Dan Perkerasan Lentur - 
Transportation (2014) menyatakan bahwa sebelum menetukan pemeliharaan atau rehabilitasi jalan pada perkerasan tertentu, sangatlah penting untuk melakukan evaluasi pada perkerasan jalan untuk menetukan penyebab dan tingkatan penurunan kondisi perkerasan jalan.

\subsection{Sistem manajemen jalan dengan Highway Development and Mangement HDM-4}

Kerali (2000) menyatakan bahwa kerangka analisis pada HDM-4 disusun berdasarkan konsep analisis siklus perkerasan jalan yang diaplikasikan untuk memprediksi lebih lanjut siklus perkerasan jalan selama umur layan biasanya jangka waktu 15 - 40 tahun. Selanjutnya, tingkat laju penurunan kondisi jalan sangat dipengaruhi oleh standar pekerjaan penanganan jalan yang telah ditetapkan baik untuk pemeliharaan maupun peningkatan jalan.

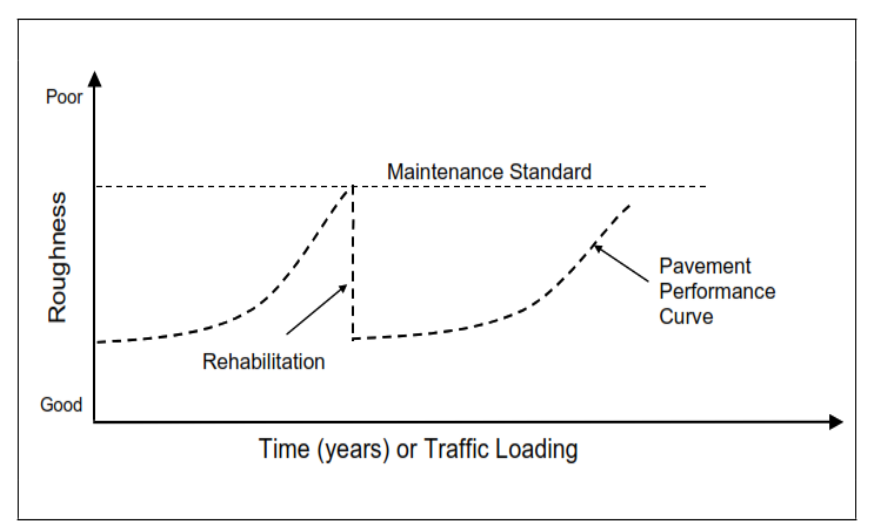

Gambar 3 Konsep dari life cycle analysis pada HDM-4 (Kerali, 2000)

\subsection{Penurunan kondisi perkerasan jalan}

Morosiuk et al (2004), dalam menganalisis penurunan kondisi jalan berdasarkan nilai kekasaran jalan, ada beberapa persamaan komponen utama penurunan kondisi jalan pada perkerasan lentur sebagai berikut:

$$
\Delta R I=\Delta R I_{s}+\Delta R I_{c}+\Delta R I_{r}+\Delta R I_{p}+\Delta R I_{e}
$$

Keterangan:

$$
\begin{aligned}
\Delta R I= & \text { total jumlah penurunan kekasaran jalan, }(\mathrm{m} / \mathrm{km} \mathrm{IRI)} \\
\Delta R I_{s}= & \text { perubahan nilai kekasaran (IRI) karena penurunan struktur } \\
& \text { selama tahun analisis, }(\mathrm{m} / \mathrm{km} \text { IRI) } \\
\Delta R I_{e}= & \text { Nilai tambahan kekasaran akibat retak selama periode analisis, } \\
& (\mathrm{m} / \mathrm{km} \text { IRI) } \\
\Delta R I_{r}= & \text { Nilai tambahan kekasaran akibat alur, }(\mathrm{m} / \mathrm{km} \mathrm{IRI)} \\
\Delta R I_{p}= & \text { nilai tambahan kekasaran akibat lubang, }(\mathrm{m} / \mathrm{km} \mathrm{IRI)} \\
\Delta \mathrm{RI}_{\mathrm{e}}= & \text { Nilai tambahan kekasaran akibat lingkungan }(\mathrm{m} / \mathrm{km} \mathrm{IRI).}
\end{aligned}
$$

Untuk penanganan jalan perkerasan lentur, menurut Morosiuk et al (2004), ada beberapa jenis permodelan penanganan jalan antara lain:

1. Pemeliharaan rutin penutupan kembali

2. Pemeliharaan lapis ulang (overlay)

3. Rekonstruksi 
Berikut adalah permodelan kondisi tingkat kekasaran pada perkerasan kaku khususnya tipe Joint Plain Concrete Pavement (JPCP) menurut ERES (1995) yang dikutip oleh Morosiuk et al (2004):

$$
I R I=I R I_{0}+0,00265(T F A U L T)+0,0291(S P A L L)+0,15 \times 10^{-6}(T R A C K)^{3}
$$

Keterangan:

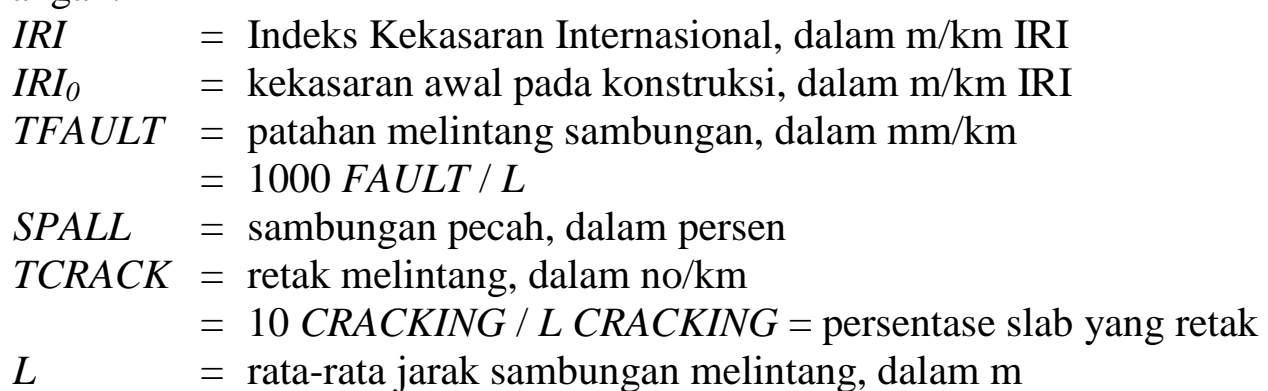

\subsection{Analisis nilai ekonomis berdasarkan Budget Plan Analysis}

Analisis biaya berdasarkan budget plan analysis pada penelitian ini meliputi biaya konstruksi, biaya pemeliharaan dan biaya rehabilitasi dengan periode analisis selama 40 tahun. Analisis biaya dihitung sesuai dengan jenis penanganan jalan berdasarkan kriteria nilai IRI dan disesuaikan dengan jenis penanganan yang berlaku di Ditjen Bina Marga Kementerian PUPR.

American Concrete Pavement Association (2012) menyatakan bahwa real discount rate biasanya digunakan pada ekonomi rekayasa untuk melihat tingkat perubahan nilai uang dari waktu ke waktu dengan mempertimbangkan fluktuasi (perkembangan) dari nilai suku bunga dan laju inflasi. Berikut adalah persamaan yang digunakan untuk menghitung real discount rate:

$$
d=\frac{1+i_{\text {int }}}{1+i_{\text {inf }}}-1
$$

Keterangan :

$d=$ real discount rate, $(\%)$.

$i_{\text {int }}=$ tingkat suku bunga, $(\%)$.

$i_{\text {inf }}=$ tingkat laju inflasi, $(\%)$.

\subsection{Lokasi penelitian dan pengumpulan data}

Lokasi penelitian adalah ruas jalan nasional batas Bireuen/Aceh Utara batas Kota Lhokseumawe/batas Aceh Utara (N.01.007.2) sepanjang 16,32 Km (Kementerian PUPR, 2015). Sumber data penelitian ini adalah data skunder diperoleh dari Balai Pelaksanaan Jalan Nasional I Banda Aceh (BPJN I) dan Satker Perencanaan dan Pengawasan Jalan Nasional Provinsi Aceh (Satker P2JN). Data skunder tersebut antara lain data volume lalu lintas, lebar badan dan lebar bahu jalan, CBR tanah dasar dan harga satuan rata-rata item pekerjaan di lingkungan BPJN I tahun 2017. Untuk Harga satuan untuk pemeliharaan rutin jalan perkerasan lentur disadur dari program penanganan jalan Road Asset Management System (RAMS) tahun 2018 di lingkungan BPJN I. Nilai inflasi selama periode analisis adalah $3,51 \%$ yang merupakan nilai rata-rata inflasi periode tahun 2016 - 2018 berdasarkan data Bank Indonesia. Tingkat suku bunga bank adalah $6 \%$ merupakan suku bunga bank sentral Indonesia pada akhir tahun 
2018. Penelitian ini menggunakan perangkat pengolah data berupa laptop serta piranti perangkat lunak yakni Microsoft Word dan Excel untuk melakukan simulasi dan analisis data.

\subsection{Jenis penanganan untuk jalan berpenutup berdasarkan nilai IRI}

Berikut adalah indeks katagori kondisi jalan berdasarkan nilai IRI menurut Ditjen Bina Marga Kementerian PUPR yang merupakan kebijakan (policy) dalam penyelenggaraan jalan:

- Baik

- Sedang

$:$ IRI $\leq 4 \mathrm{~m} / \mathrm{km}$

- Rusak Ringan

$: 4<\mathrm{IRI} \leq 8 \mathrm{~m} / \mathrm{km}$

- Rusak Berat

$: 8<\mathrm{IRI} \leq 12 \mathrm{~m} / \mathrm{km}$

- Kemantapan Jalan

: IRI $>12 \mathrm{~m} / \mathrm{km}$

\subsection{Penentuan skenario simulasi Budget Plan Analysis}

Penelitian ini, ada 2 (dua) jenis kriteria pemicu yakni kriteria pemicu berdasarkan nilai IRI dan kriteria pemicu berdasarkan umur masa layan.

\section{A. Simulasi pada perkerasan lentur}

1. Simulasi 1 (Flexible Pavement): SF01

Kriteria penanganan berdasarkan nilai IRI:

- $0<$ IRI $<4 \quad$ : Pemeliharaan rutin

- $4 \leq \mathrm{IRI}<6 \quad$ : Rehabilitasi minor ke - 1 (overlay $40 \mathrm{~mm}$ )

- $6 \leq \mathrm{IRI}<7 \quad$ : Rehabilitasi minor ke -2 (overlay $60 \mathrm{~mm}$ )

- $7 \leq \mathrm{IRI}<8 \quad$ : Rehabilitasi mayor (overlay $100 \mathrm{~mm}$ )

- IRI $\geq 8 \quad$ : Rekonstruksi

2. Simulasi 2 (Flexible Pavement): SF02

Kriteria penanganan berdasarkan nilai IRI:

- $0<$ IRI $<4$ : Pemeliharaan rutin

- $4 \leq \mathrm{IRI}<6 \quad$ : Rehabilitasi minor ke - 1 (overlay $40 \mathrm{~mm}$ )

- $6 \leq \mathrm{IRI}<8 \quad$ : Rehabilitasi minor ke -2 (overlay $60 \mathrm{~mm}$ )

- $8 \leq \mathrm{IRI}<10 \quad$ : Rehabilitasi mayor (overlay $100 \mathrm{~mm}$ )

- IRI $\geq 10 \quad$ : Rekonstruksi

3. Simulasi 3 (Flexible Pavement): SF03

Kriteria pemicu penanganan berdasarkan periode masa layan setiap 5 tahun:

- $0<$ tahun $<40$ : Pemeliharaan rutin (kecuali ada penanganan lain)

- Tahun ke-5 : Rehabilitasi minor Ke -1 (overlay $40 \mathrm{~mm}$ )

- Tahun ke-10 : Rehabilitasi minor Ke -2 (overlay $60 \mathrm{~mm}$ )

- Tahun ke-15 : Rehabilitasi mayor (overlay $100 \mathrm{~mm}$ )

- Tahun ke-20 : Rekonstruksi

- Tahun ke-25 : Rehabilitasi minor Ke -3 (overlay $40 \mathrm{~mm}$ )

- Tahun ke-30 : Rehabilitasi minor Ke -4 (overlay $60 \mathrm{~mm}$ )

- Tahun ke-35 : Rehabilitasi mayor (overlay $100 \mathrm{~mm}$ )

- Tahun ke-40 : Rekonstruksi

Perhitungan besaran efek penanganan/pemeliharaan (work road effect) jalan dihitung berdasarkan nilai IRI. Nilai IRI setelah penanganan jalan perkerasan lentur khususnya rehabilitasi mayor adalah sebesar 3,0 m/km IRI (Direktur 
Preservasi Jalan, 2016). Sedangkan pengurangan nilai IRI setelah penanganan pada pemeliharaan rutin jalan dan rehabilitasi minor mengunakan hasil analisis dengan tingkat sensitifitas terhadap pengurangan nilai IRI sebesar 0,01 yang merupakan nilai standar (default) dari manual HDM-4.

\section{B. Simulasi pada perkerasan kaku}

Penanganan pada perkerasan kaku dilakukan berdasarkan periode masa layan dengan jenis pekerjaan sebagai berikut:

- Pemeliharaan/perbaikan dowel pada perkerasan kaku (Transver Fault).

- Pemeliharaan/perbaikan beton yang pecah/gompal (Spalling).

- Pemeliharaan/perbaikan retak (memanjang dan melintang) (Cracking).

- Pemeliharan kekasaran permukaan dengan Diamond Grinding pada setiap model dilakukan pada tahun ke-10 dan tahun ke-30.

- Sedangkan pemeliharaan drainase aliran permukaan dengan Diamond Grooving pada setiap model hanya dilakukan pada tahun ke-20.

Berikut kriteria pemicu penanganan pada tiap -tiap model perkerasan kaku:

1. Simulasi 1 (Rigid Pavement): SR01

Kriteria pemicu penanganan berdasarkan masa layan setiap 5 tahun.

2. Simulasi 2 (Rigid Pavement): SR02

Kriteria pemicu penanganan berdasarkan masa layan setiap 8 tahun.

3. Simulasi 3 (Rigid Pavement): SR03

Kriteria pemicu penanganan berdasarkan masa layan setiap 10 tahun.

\subsection{Metode pengolahan data}

Beberapa tahapan atau metode pengolahan data yang digunakan dalam penelitian ini sebagai berikut:

- Analisis data Lalu Lintas Harian Rata-rata (LHR), California Bearing Ration (CBR) desain, Derajat Kejenuhan (DS) dan Cummulative Equivalent Standard Axle (CESA).

- Perhitungan desain tebal pada kedua jenis perkerasan dihitung secara manual berdasarkan hasil pengolahan data skunder yang telah didapatkan.

- Analisis penurunan kondisi jalan pada kedua jenis perkerasan.

- Analisis biaya penanganan jalan dihitung berdasarkan perhitungan kebutuhan volume material berdasarkan hasil perhitungan tebal perkerasan jalan, data teknis lebar jalan dan harga satuan pekerjaan. Komponen biaya yang dihitung pada perkerasan lentur antara lain: volume laston AC-WC, AC-BC dan ACBase, volume tack coat dan prime coat, volume agregat lapis pondasi dan lapis pondasi. Sedangkan pada perkerasan kaku, komponen biaya yang dihitung meliputi: volume slab beton, kebutuhan dowel dan tulangan pengikat, lapis pondasi LMC, lapis pondasi atas dan lapis pondasi.

- Analisis nilai ekonomi budget plan analysis dengan metode real discount rate.

\section{Hasil dan Pembahasan}

\subsection{Hasil analisis desain tebal perkerasan}

Berdasarkan hasil perhitungan dan analisis yang telah dilakukan, berikut disampaikan hasil analisis perencanaan desain tebal perkerasan lentur: 

a. Laston $\mathrm{AC}-\mathrm{WC}$
: $\quad 40 \mathrm{~mm}$
b. Laston $\mathrm{AC}-\mathrm{BC}$
c. Laston AC-Base (Rekonstruksi ke-1)
$60 \mathrm{~mm}$
d. Laston AC-Base (Rekonstruksi ke-2 \& ke-3)
$210 \mathrm{~mm}$
e. Lapis Pondasi Atas (LPA)
$245 \mathrm{~mm}$
f. Lapis Pondasi
: $300 \mathrm{~mm}$
: $300 \mathrm{~mm}$

Perkerasan kaku yang digunakan pada analisis adalah tipe JPCP dengan dowel sebagai alat bantu transver beban. Berikut adalah hasil analisis desain tebal perkerasan untuk perkerasan kaku:
a. Tebal Plat Beton fc' $35 \mathrm{MPa}$
: $305 \mathrm{~mm}$
b. Ukuran Dowel
: D $38 \mathrm{~mm}$ - jarak $300 \mathrm{~mm}$
c. Ukuran Tulangan Pengikat (asumsi)
: 4 D16 dan Sengkang Ø10-250 mm
d. Bahu beton
e. Lapis Pondasi LMC
: Tidak dihitung dalam simulasi
f. Lapis Pondasi Atas (LPA)
g. Lapis Pondasi
: $150 \mathrm{~mm}$
: $300 \mathrm{~mm}$ (sebagai drainage layer)
: $300 \mathrm{~mm}(\mathrm{CBR} 3,0 \%)$

Nilai DS yang digunakan sebagai indikator pelebaran jalan/peningkatan kapasitas adalah $\leq 0,85$ dengan konfigurasi jalan awal yakni $2 / 2$ UD. Berdasarkan hasil analisis, pada tahun ke-23 (tahun 2042) nilai DS sudah mencapai 0,88 (DS $>0,85)$ sehingga perlu dilakukan pelebaran jalan dari konfigurasi jalan dari 2/2 UD menjadi 4/2 D. Pada tahun terakhir analisis, nilai DS masih berada dibawah ambang batas maksimum yakni 0,81 (DS < 0,85) sehingga belum perlu dilakukan peningkatan kapasitas dari konfigurasi jalan 4/2 D menjadi 6/2 D.

\subsection{Hasil Analisis Simulasi Perkerasan Lentur (SF01)}

Berdasarkan hasil analisis, SF01 memiliki tingkat kenyamanan pengguna jalan yang cukup baik mengingat kondisi rusak ringan hanya terjadi pada pada tahun ke -23 (IRI 9,16 m/km) sedangkan tahun lainnya berada pada kondisi baik dan sedang (IRI $\leq 8,0 \mathrm{~m} / \mathrm{km}$ ). Biaya pembangunan perkerasan lentur untuk ketiga model adalah sama yakni Rp. 225,18 Milyar. Rekonstruksi jalan dilakukan pada tahun ke-24 dengan biaya Rp. 366,84 Milyar. Jenis pemeliharaan jalan terakhir SF01 adalah RH_AC100 pada tahun ke-37 sedangkan rekonstruksi ke-2 diprediksikan terjadi diluar periode analisis budget plan yakni pada tahun ke-41 sampai tahun ke-42. Nilai IRI tahun ke-40 adalah $6,38 \mathrm{~km} / \mathrm{m}$ IRI dengan biaya kumulatif atau biaya budget plan selama periode analisis 40 tahun adalah Rp. 1.014,85 Milyar.

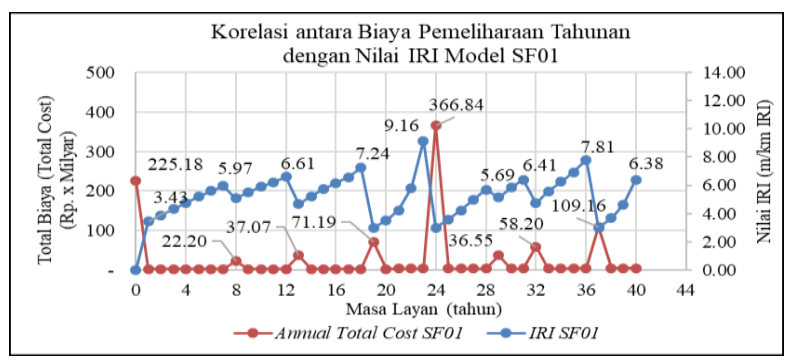

Gambar 4 Korelasi antara Biaya Pemeliharaan Tahunan dengan Nilai IRI Model SF01

Simulasi Biaya Penanganan Jalan Antara Perkerasan Kaku Dan Perkerasan Lentur Ade Mulyawan, Sofyan M. Saleh, Renni Anggraini 


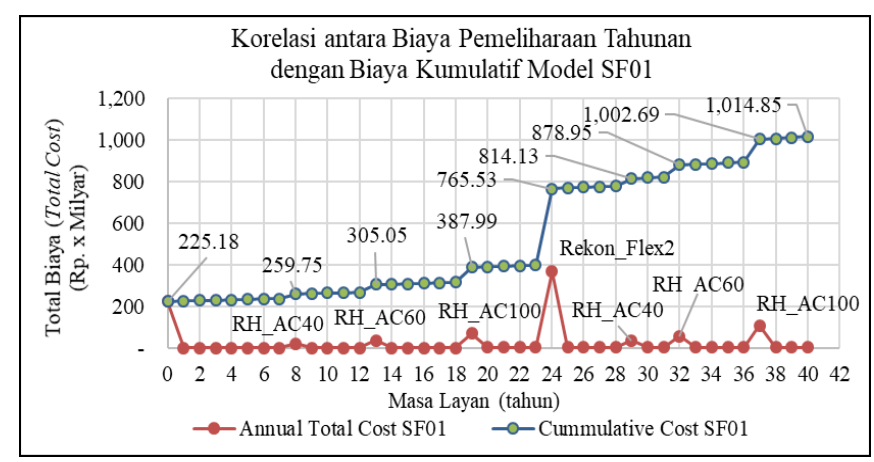

Gambar 5 Korelasi antara Biaya Pemeliharaan Tahunan dengan Biaya Kumulatif Model SF01

Analisis yang sama juga dilakukan pada SF02 dan SF03. SF02 memiliki tingkat kenyamanan pengguna jalan yang lebih rendah dari SF01 dimana terdapat dua kondisi rusak ringan yakni IRI 8,72 m/km (tahun ke-20) dan IRI 11,96 m/km (tahun ke-26). SF02 memiliki masa siklus rekonstruksi yang lebih panjang (tahun ke-27) dari SF01 dengan biaya rekonstruksi sebesar Rp. 393,93 Milyar. Biaya budget plan SF02 selama periode analisis 40 tahun adalah Rp. 1.061,60 Milyar. Selanjutnya, pada SF03 terdapat satu kondisi rusak berat (IRI 12,46 m/km) pada tahun ke-39, dua kondisi rusak ringan yakni pada tahun ke-19 dan ke-34 dengan nilai IRI $8,54 \mathrm{~m} / \mathrm{km}$ dan $8,29 \mathrm{~m} / \mathrm{km}$. Rekontruksi SF03 dilakukan sebanyak dua kali dengan biaya rekonstruksi ke-1 (tahun ke-20) sebesar Rp. 333,60 Milyar dan biaya rekonstruksi ke-2 (tahun ke-40) sebesar Rp. 607,08 Milyar. Biaya budget plan model SF03 selama periode analisis 40 tahun adalah Rp. 1.564,34 Milyar.

\subsection{Hasil Analisis Simulasi Perkerasan Kaku (SR01)}

Hasil analisis menunjukkan bahwa IRI maksimum senilai $7,77 \mathrm{~m} / \mathrm{km}$ (kondisi sedang) terjadi pada tahun ke-40. Biaya pembangunan untuk ketiga model yakni SR01, SR02 dan SR03 adalah Rp. 300,90 Milyar. Biaya budget plan model SR01 selama masa layan 40 tahun merupakan biaya terbesar diantara model perkerasan kaku lainnya dengan nilai Rp. 667,23 Milyar.

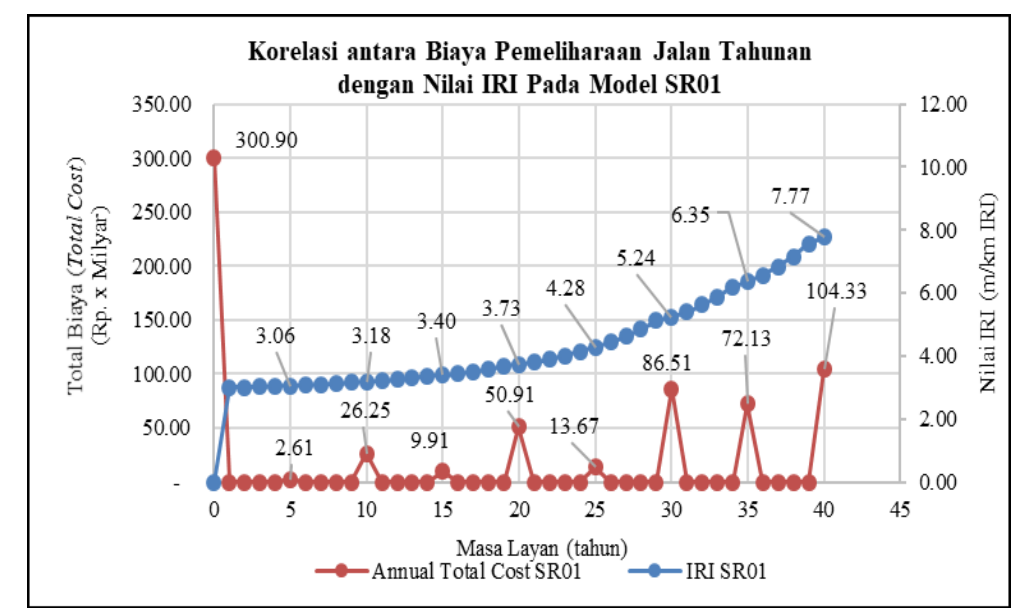

Gambar 6 Korelasi antara Biaya Pemeliharaan Tahunan dengan

Nilai IRI Model SR01

Simulasi Biaya Penanganan Jalan Antara Perkerasan Kaku Dan Perkerasan Lentur Ade Mulyawan, Sofyan M. Saleh, Renni Anggraini 


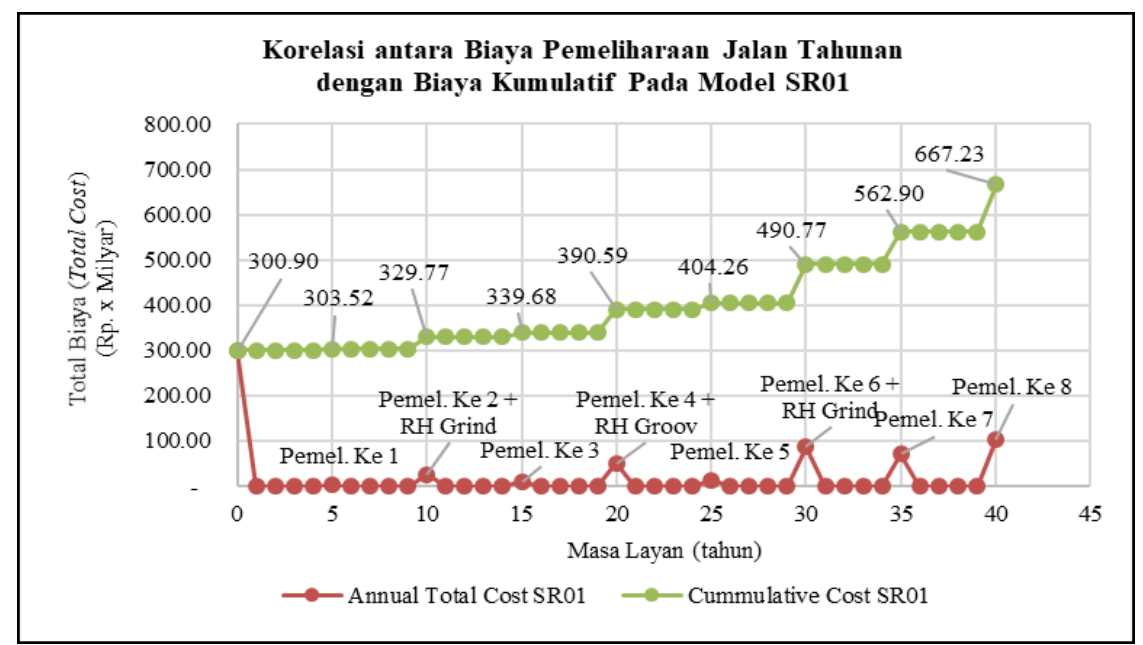

Gambar 7 Korelasi antara Biaya Pemeliharaan Tahunan dengan Biaya Kumulatif Model SR01

Analisis yang sama juga dilakukan pada SR02 dan SR03. Pada SR02, nilai IRI maksimum 9,14 m/km (kondisi rusak ringan) terjadi pada tahun ke-40. Biaya budget plan selama periode analisis 40 tahun model SR02 adalah Rp. 652,83 Milyar. Biaya tersebut sedikit lebih rendah dari model SR01 namun tingkat kenyaman model SR02 lebih rendah dari model SR01. Pada SR03, IRI maksimum juga terjadi pada tahun ke-40 sebesar 10,09 m/km (kondisi rusak ringan). SR03 memiliki biaya budget plan selama periode analisis 40 tahun terendah diantara model lainnya senilai Rp. 646,72 Milyar namun dengan tingkat kenyamanan pengguna jalan yang paling buruk diantara model perkerasan kaku lainnya.

\subsection{Perbandingan Biaya Budget Plan Perkerasan Kaku dengan Perkerasan Lentur}

Pada Gambar 8 merupakan grafik hasil perbandingan budget plan analysis berdasarkan beberapa variabel penanganan jalan.

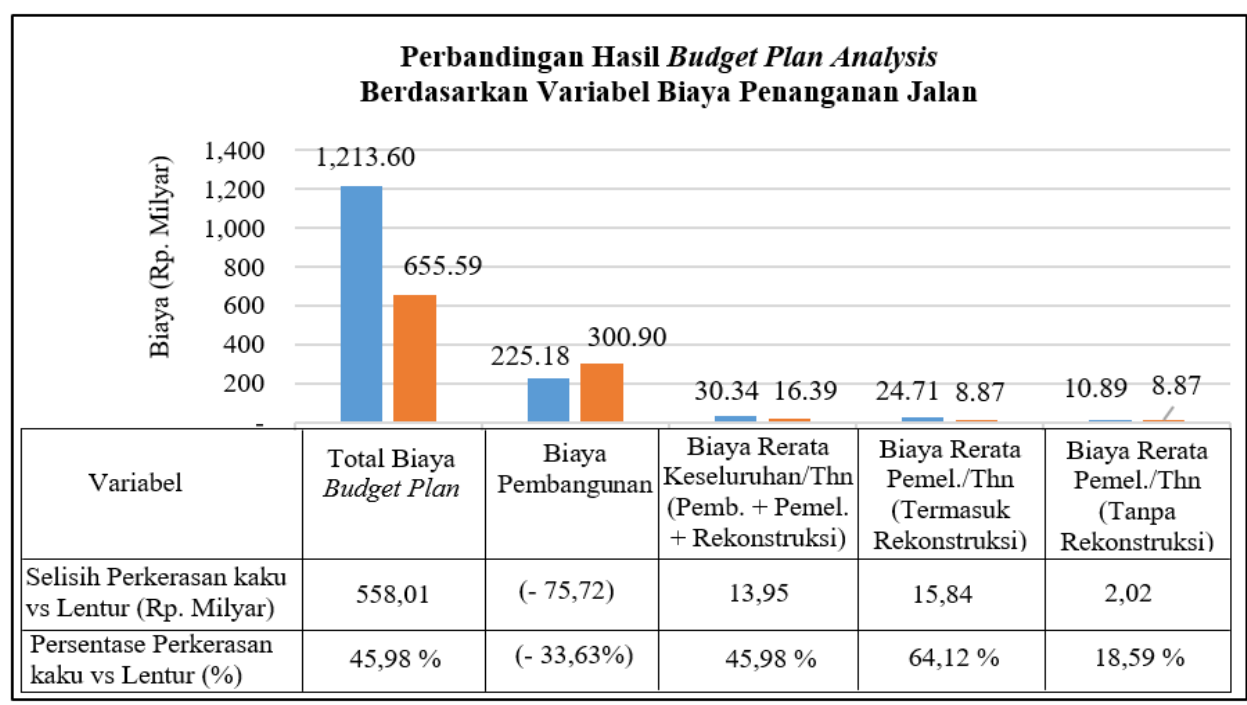

Gambar 8 Perbandingan Hasil Budget Plan Analysis Berdasarkan Variabel Biaya Penanganan Jalan 
Berdasarkan Gambar 8, biaya total Budget Plan perkerasan kaku lebih hemat 45,98 \% dari perkerasan lentur dengan total biaya penanganan pada perkerasan kaku sebesar Rp. 655,59 Milyar sedangkan total biaya perkerasan lentur rata-rata senilai Rp. 1.213,60 Milyar dalam periode analisis selama 40 tahun. Sedangkan biaya pembangunan (initial cost) perkerasan kaku lebih mahal $33,63 \%$ dari perkerasan lentur namun biaya pemeliharaan rata-rata temasuk biaya rekonstruksi per tahun pada perkerasan kaku lebih hemat Rp. 15,84 Milyar atau $64,12 \%$ dari perkerasan lentur. Biaya pemeliharaan rata-rata tidak termasuk biaya rekonstruksi per tahun perkerasan kaku juga lebih hemat Rp. 2,02 Milyar atau $18,59 \%$ lebih ekonomis dibandingkan dengan perkerasan lentur.

\section{Kesimpulan dan Saran \\ 4.1 Kesimpulan}

Analisis budget plan pada penelitian ini menggunakan tingkat suku bunga $6 \%$ dan nilai inflasi 3,51\% dengan asusmi bahwa nilai tersebut merupakan nilai investasi minimum selama periode analisis 40 tahun. Model Simulasi Perkerasan Kaku ke-1 (SR01) merupakan pilihan terbaik dan ekonomis berdasarkan budget plan analysis dari segi biaya pemeliharaan dan tingkat kenyamanan yang paling baik dengan nilai IRI akhir periode analisis sebesar 7,77 m/km IRI dibandingkan model perkerasan lainnya. Biaya penanganan berdasarkan budget plan perkerasan kaku lebih hemat 45,98 \% dari perkerasan lentur selama periode analisis 40 tahun. Biaya pembangunan perkerasan kaku lebih mahal 33,63\% namunl dalam jangka panjang, biaya pemeliharaan perkerasan kaku rata-rata termasuk biaya rekonstruksi lebih hemat $64,12 \%$ termasuk biaya rekonstruksi dan $18,59 \%$ lebih hemat bila tidak termasuk biaya rekonstruksi. Berdasarkan hasil simulasi diketahui bahwa perkerasan kaku terbukti lebih hemat dalam pembiayaan jangka panjang berdasarkan budget plan analysis. Berdasarkan hasil analisis budget plan, bila dilakukan simulasi dengan tingkat suku bunga yang lebih besar dari $6 \%$ yakni $10 \%$ dan $12 \%$ dengan nilai inflasi tetap 3,51\% dengan pola penanganan jalan yang sama (identik), maka dapat diprediksikan bahwa tingkat perbandingan biaya penanganan budget plan perkerasan kaku akan lebih besar dari nilai perbandingan saat ini yakni 45,98\% bahkan bisa mencapai diatas angka lebih dari 50\%.

\subsection{Saran}

Diharapkan dari hasil penelitian ini, pemerintah sebagai pengambil kebijakan mendapat masukkan dalam perencanaan pemograman sistem jaringan jalan khususnya penerapan metode budget plan analysis dalam perencanaan pemograman penanganan jalan sehingga anggaran pembangunan dan pemeliharaan yang tersedia dapat lebih dioptimalkan. Penelitian selanjutnya disarankan agar meninjau variabel suku bunga bank konvensional dalam analisis budget plan serta meninjau variabel defleksi sebagai variabel utama dalam permodelan penurunan kondisi jalan sehingga dapat diketahui kebutuhan biaya penanganan jalan yang lebih akurat dan informatif sebagai bahan pertimbangan dalam penyusunan terutama untuk kebutuhan anggaran penanganan jalan.

Simulasi Biaya Penanganan Jalan Antara Perkerasan Kaku Dan Perkerasan Lentur Ade Mulyawan, Sofyan M. Saleh, Renni Anggraini 


\section{Daftar Kepustakaan}

American Concrete Pavement Association, 2012. Life Cycle Cost Analysis: A Tool for Better Pavement Invesment and Engineering Decicions. ACPA. Rosemont- Illinois.

Direktorat Jenderal Bina Marga, 2017. Manual Desain Perkerasan Jalan Nomor 02/M/BM/2017, Kementerian PUPR. Jakarta.

Direktorat Preservasi Jalan, 2016. Bahan Paparan Workshop Penajaman Pemograman dan Pemaketan Preservasi TA. 2017 tanggal 27-30 September 2016 di Batam. Ditjen Bina Marga Kementerian PUPR. Jakarta.

Direktur Preservasi, 2006. Ralat Petunjuk Penyusunan Program Preservasi Jalan Tahun Anggaran 2017. Surat Direktur Preservasi Jalan Ditjen Bina Marga No.PR.0102-Bn/92 tanggal 17 Februari 2016. Ditjen Bina Marga Kementerian PUPR. Jakarta.

Federal Highway Administration of U.S Department of Transportation, 2014. Concrete Pavement Preservation Guide. FHWA. IOWA-United State of America.

Kementerian PUPR, 2015. Keputusan Menteri Pekerjaan Umum dan Perumahan Rakyat No. 248/KPTS/M/2015 tentang Penetapan Ruas Jalan Dalam Jaringan Jalan Primer Menurut Fungsinya Sebagai Jalan Arteri (JAP) dan Jalan Kolektor -1 (JKP-1). Jakarta.

Kerali, H.G.R., 2000. Highway Development \& Mangement (HDM-4) Volume One: Overview of HDM-4. The World Road Assosiation (PIARC) on behalf of the ISOHDM Sponsors. Paris and The World Bank Wahington DC.

Morosiuk, G., Riley,M. J., Odoki, J.B., 2004. Highway Development \& Mangement (HDM-4) Volume Six: Modelling Road Deterioration and Works Effect Version 2. The World Road Assosiation (PIARC) on behalf of the ISOHDM Sponsors. Paris and The World Bank Wahington DC.

Robinson, R., Thagesen, B., 2004. Road Engineering for Development Second Edition. Spons Press. London.

Saleh,. S. M., Sjafruddin, A., Frazila., R.B., Tamin, O.Z., 2009. Pengaruh Muatan Truk Berlebih Terhadap Biaya Pemeliharaan Jalan. Jurnal Transportasi FSTPT. vol. 9. no. 1. pp. 79-89.

Syafriana, Saleh, S.M., Anggraini, R., 2015. Evaluasi Umur Layan dengan Memperhitungkan Beban Berlebih di Ruas Jalan Lintas Timur Provinsi Aceh. Jurnal Transportasi FSTPT. vol. 15. no. 2. pp. 115-124. 